\title{
Pengaruh Konsumsi Kopi terhadap Waktu Reaksi Mahasiswi FK Ukrida Angkatan 2014 pada Berbagai Fase Siklus Menstruasi
}

\author{
William $^{1}$, Flora Rumiati ${ }^{1}$, Un Gerry Namyu ${ }^{2}$ \\ ${ }^{1}$ Staf Pengajar Bagian Fisiologi, Fakultas Kedokteran Universitas Kristen Krida Wacana \\ ${ }^{2}$ Mahasiswa Fakultas Kedokteran Universitas Kristen Krida Wacana \\ Alamat Korespondensi: william@ukrida.ac.id
}

\begin{abstract}
Abstrak
Pemeriksaan waktu reaksi adalah pemeriksaan yang bertujuan untuk menilai kinerja sesorang, dan merepresentasikan tingkat koordinasi muskuloskeletal. Beberapa hal yang dapat mempengaruhi pemeriksaan waktu reaksi antara lain: intensitas dan durasi stimulus, usia, jenis kelamin, efek latihan, olahraga, dan minum kopi. Waktu reaksi perempuan sangat bergantung pada fase siklus menstruasi, yang akan mempengaruhi kinerja seorang perempuan. Kopi selama ini diketahui dapat meningkatkan waktu reaksi. Penelitian ini bertujuan untuk mengetahui pengaruh konsumsi kopi pada perempuan dalam berbagai fase siklus menstruasi. Subjek penelitian ini adalah mahasiswi Fakultas Kedokteran Universitas Kristen Krida Wacana (Ukrida) Angkatan 2014 berusia 20-21 tahun. Alat yang digunakan untuk mengukur waktu reaksi adalah lakassidaya. Pemeriksaan dilakukan sebelum dan sesudah meminum kopi pada ketiga fase menstruasi. Pada penelitian ini didapatkan waktu reaksi sebelum dan sesudah minum kopi pada fase menstruasi sebagai berikut: $188,53 \pm 22,61 \mathrm{~ms}$ dan $171,3 \pm 18,61 \mathrm{~ms}$; fase proliferasi: $204,69 \pm 30,97 \mathrm{~ms}$ dan $180,44 \pm 25,21 \mathrm{~ms}$; fase sekretori: $222,14 \pm 33,47 \mathrm{~ms}$ dan $188,37 \pm 22,7$ ms. Terdapat perbedaan bermakna sebelum dan sesudah minum kopi pada fase menstruasi, fase proliferasi (p:0,0001) dan fase sekretori (p:0,006). Terdapat perbedaan bermakna antara fase menstruasi dengan fase proliferasi, fase menstruasi dengan fase sekretori, dan antara fase proliferasi dengan fase sekretori (p:0,0001). Simpulan: Konsumsi kopi mempercepat waktu reaksi pada semua fase menstruasi.
\end{abstract}

Kata kunci: waktu reaksi, menstruasi, konsumsi kopi, lakassidaya.

\section{The Effect of Coffee Consumption on Student Reaction Time Ukrida Medical Faculty Class of 2014 at Various Phases of Menstrual Cycle}

\begin{abstract}
Reaction time is used to measure the performance of a person and represents the level of musculoskeletal coordination. Factors that affect reaction time include intensity and duration of the stimulus, age, sex, repetition, and exercise. In women, reaction time is very dependent on the menstrual cycle. Coffee has been known to increase reaction time. The aim of this study was to determine the effect of coffee consumption on women's reaction time in various phases in menstrual cycles. The study was conducted on female medical students class of 2014, aged 20-21 years. Reaction time was measured before and after drinking coffee in all phases of menstruations using lakassidaya apparatus. The study found that there were significant differences in the reaction times before and after drinking coffee in all phases. The average reaction times (in milliseconds) were as follows; the menstrual phase (188.53 \pm 22.61 and $171.3 \pm 18.61)$, proliferation phase (204.69 \pm 30.97 and $180.44 \pm 25.21, p: 0.0001)$ and secretory phase (222.14 \pm 33.47 and $188.37 \pm 22.7, p$ : 0.006). The study also found that there were significant differences between the menstrual and the proliferation phases, the menstrual and the secretory phases and between the proliferation and
\end{abstract}


secretory phases ( $p: 0.0001)$. In conclusion,coffee consumption can speed up reaction time at all phases of menstruation.

Keywords: Reaction time, menstruation, coffee consumption, lakassidaya.

\section{Pendahuluan}

Pemeriksaan waktu reaksi adalah pemeriksaan yang dilakukan untuk mengukur waktu yang diperlukan seseorang untuk berespon setelah menerima rangsang sensorik. Pemeriksaan ini bertujuan untuk menilai kinerja seseorang dan merepresentasikan tingkat koordinasi muskuloskeletal. ${ }^{1}$ Banyak faktor yang dapat mempengaruhi waktu reaksi seseorang, antara lain: intensitas dan durasi stimulus, usia, jenis kelamin, efek latihan dengan pemeriksaan waktu reaksi, ${ }^{2}$ olahraga, ${ }^{3}$ siklus menstruasi, ${ }^{4}$ dan konsumsi stimulan seperti kafein. ${ }^{5}$ Pemeriksaan waktu reaksi dapat dibagi menjadi simple reaction time, recognition reaction time, dan choice reaction time. Pemeriksaan simple reaction time hanya menggunakan satu stimulus dan satu respons. Pada recognition reaction time terdapat beberapa stimuli yang harus direspons dan yang tidak harus direspons. ${ }^{6}$ Pada choice reaction time terdapat banyak stimulus serta banyak respons dan subjek harus memberikan respons yang sesuai dengan stimulus yang diberikan. ${ }^{6}$

Kopi merupakan minuman paling banyak diminum di dunia dan komoditi kedua terbesar yang diperdagangkan setelah minyak bumi. Kopi telah dikonsumsi selama lebih dari 1.000 tahun dan pada saat ini konsumsi kopi telah mencapai lebih dari 400 milyar gelas kopi per tahun. ${ }^{7}$ Komposisi kimiawi dari kopi antara lain monosakarida, polisakarida, lemak, wax, asam, fenol, asam amino, protein, kafein, trigenolin, dan mineral. ${ }^{7}$ Kafein tidak hanya terdapat pada kopi, tetapi juga terdapat pada lebih dari 60 tanaman. Kafein sendiri merupakan nutrien kecil pada tanaman dan tidak esensial untuk tanaman itu sendiri, dan dipakai oleh tanaman sebagai insektisida alami. Kafein pada manusia bermanfaat sebagai psikostimulan, yang dapat meningkatkan kewaspadaan, membuat otak tetap terjaga dan meningkatkan performa fisik. ${ }^{8}$

Menstruasi merupakan proses fisiologis yang terjadi pada perempuan dan ditandai dengan keluarnya darah dari vagina. Menstruasi memiliki siklus yang sangat dipengaruhi oleh kerja hormon. Siklus menstruasi dapat dibagi menurut perubahan yang terjadi di ovarium dan yang terjadi di endometrium. Siklus menstruasi yang terjadi di ovarium terdiri atas fase folikular, fase ovulasi, dan fase luteal, sedangkan siklus menstruasi yang terjadi di endometrium terdiri atas fase menstruasi, fase proliferasi, dan fase sekretori. ${ }^{10}$

Siklus menstruasi dapat mempengaruhi hasil dari pemeriksaan waktu reaksi, waktu reaksi memendek pada fase menstruasi, memanjang pada fase proliferasi, dan yang paling panjang pada fase sekretori. Perubahan waktu reaksi ini dapat menurunkan produktivitas perempuan, terutama ketika berada pada fase proliferasi dan fase sekretori. ${ }^{4}$ Karena kafein yang terdapat pada kopi dapat meningkatkan kecepatan waktu reaksi seseorang, ${ }^{5}$ maka penelitian ini ingin melihat pengaruh konsumsi kopi terhadap waktu reaksi perempuan pada berbagai fase menstruasi endometrium.

\section{Metode Penelitian}

Subjek penelitian ini adalah mahasiswi Fakultas Kedokteran Ukrida Angkatan 2014, berusia 20-21 tahun. dan memiliki siklus menstruasi teratur. Kriteria eksklusi mencakup: sedang hamil, memakai kontrasepsi hormonal, memiliki gangguan penglihatan, merokok, minum alkohol, memiliki gangguan pernapasan, memiliki gangguan kardiovaskular, dan menggunakan obat-obatan yang dapat menganggu kognitif. Sampel yang digunakan pada penelitian ini berjumlah 34 orang.

\section{Penetapan Fase-Fase Menstruasi}

Penetapan fase-fase menstruasi dilakukan dengan cara mahasiswi melaporkan mulainya menstruasi, kemudian ditetapkan fase-fase pada siklus menstruasinya. Fase menstruasi yaitu hari ke-1 sampai dengan hari 
ke-4 setelah mulai suatu menstruasi. Fase proliferasi berlangsung pada hari ke-5 sampai dengan hari ke-12. Fase sekretori terjadi pada hari ke-16 sampai dengan hari ke-23. ${ }^{9}$

\section{Pemeriksaan Waktu Reaksi}

Pemeriksaan waktu reaksi menggunakan alat lakassidaya. Pemeriksaan dilakukan pada setiap fase menstruasi dan dilakukan pemeriksaan sebelum dan 10 menit sesudah minum kopi. Kopi yang digunakan adalah kopi sachet $25 \mathrm{~g}$ dengan kadar kafein $85 \mathrm{mg}$. Pemeriksaan waktu reaksi dilakukan pada ruangan yang tenang dan subjek penelitian duduk senyaman mungkin menghadap ke sumber cahaya. Pemeriksaan dilakukan dengan cara pemeriksa menekan tombol pada lakassidaya alat yang akan menimbulkan sumber cahaya menyala dan pengukur waktu berjalan. Subjek penelitian harus secepat mungkin menekan tombol pada mouse untuk menghentikan waktu yang berjalan pada lakassidaya. Waktu antara stimulasi cahaya sampai pada saat subjek penelitian menekan mouse akan tertera pada alat. Satuan yang tertera pada lakassidaya adalah milidetik. Pencatatan waktu reaksi dilakukan sebanyak 15 kali untuk satu kali pemeriksaan. Lima data pertama tidak akan dipakai karena dianggap sebagai waktu penyesuaian subjek dengan lakassidaya. Sepuluh data yang didapatkan akan dirata-rata dan dipakai sebagai nilai waktu reaksi subjek penelitian. ${ }^{11}$

\section{Analisis Statistik}

Data yang terkumpul diolah menggunakan IBM SPSS Statistic 24. Uji statistik untuk perbandingan waktu reaksi pada fase-fase menstruasi menggunakan uji repeated ANOVA. Sedangkan uji statistik untuk sebelum dan sesudah minum kopi digunakan uji t berpasangan.

\section{Keterangan Lolos Kaji Etik}

Penelitian ini telah lolos kaji etik dari Komisi Etik Penelitian FK Ukrida, no 434/SLKE-IM/UKKW/FK/KE/XII/2017.

\section{Hasil Penelitian}

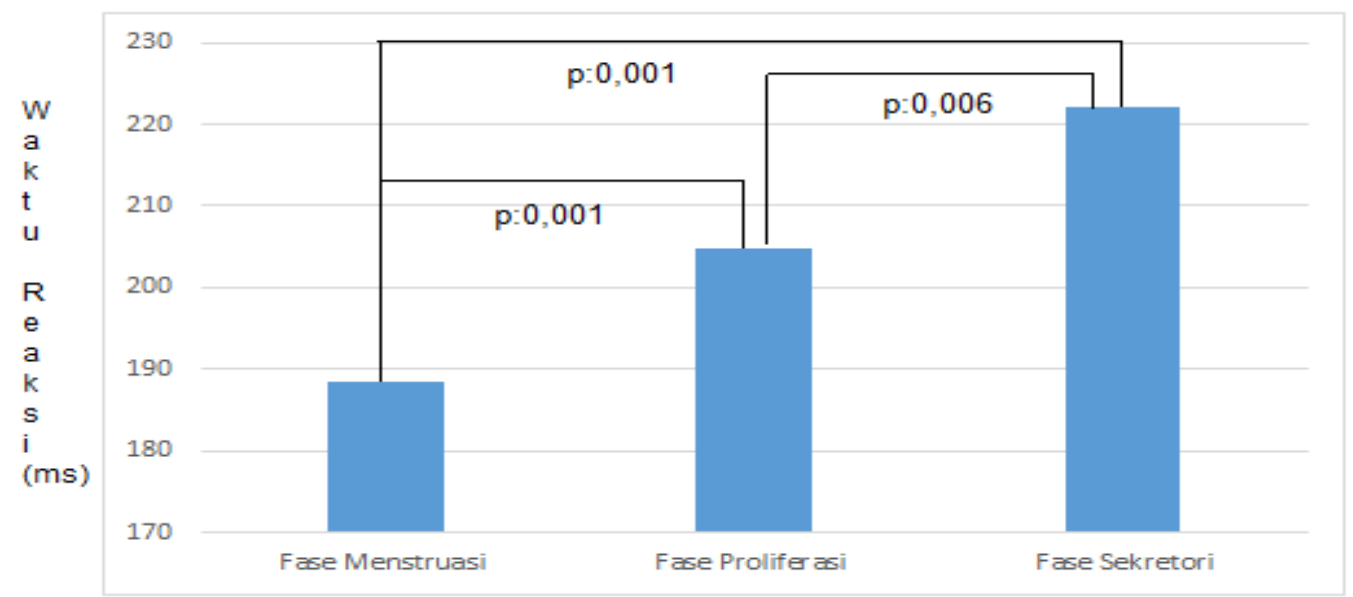

Gambar 1. Perbedaan Waktu Reaksi pada berbagai Fase Menstruasi

$(\mathrm{n}=34)$, fase menstruasi vs fase proliferasi $(188,53 \pm 22,61 \mathrm{~ms}$ vs $204,69 \pm 30,97 \mathrm{~ms} ; \mathrm{p}<0,05)$, fase menstruasi vs fase sekretori $(188,53 \pm 22,61 \mathrm{~ms}$ vs $222,14 \pm 33,47 \mathrm{~ms} ; \mathrm{p}<0,05)$, fase proliferasi vs fase sekretori $(204,69 \pm 30,97 \mathrm{~ms}$ vs $222,14 \pm 33,47 \mathrm{~ms}$; $\mathrm{p}<0,05)$. 


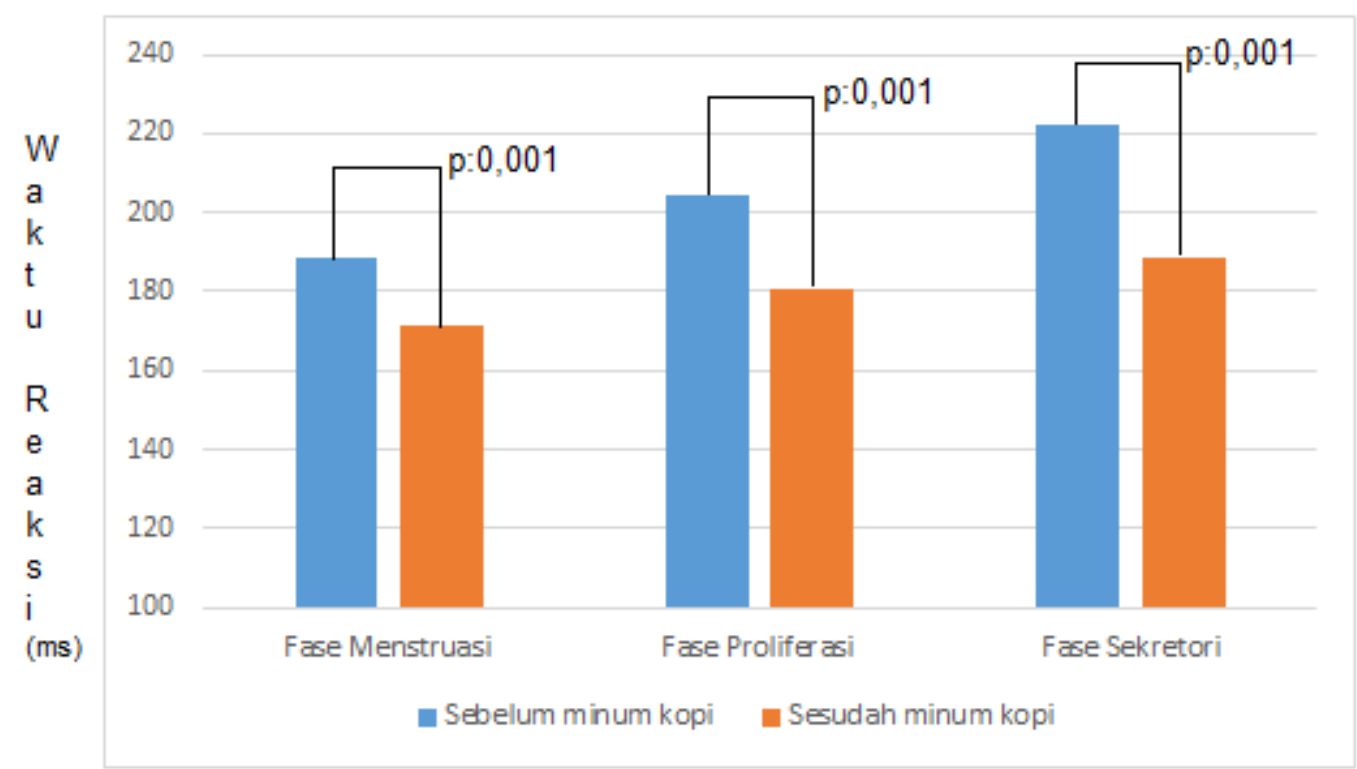

\section{Gambar 2. Perbedaan Waktu Reaksi Sebelum dan Sesudah Minum Kopi pada Berbagai Fase Menstruasi}

$(\mathrm{n}=34)$, fase menstruasi sebelum dan sesudah minum kopi $(188,53 \pm 22,6 \mathrm{~ms}$ vs $171,3 \pm 18,61 \mathrm{~ms}$; $\mathrm{p}<0,05)$, fase proliferasi sebelum dan sesudah minum kopi $(204,69 \pm 30,97 \mathrm{~ms}$ vs $180,44 \pm 25,21 \mathrm{~ms}$; $\mathrm{p}<0,05)$, Fase sekretori sebelum dan sesudah minum kopi $(222,14 \pm 33,47 \mathrm{~ms}$ vs $188,37 \pm 22,7 \mathrm{~ms}$; $\mathrm{p}<0,05)$.

\section{Diskusi}

Grafik pertama menunjukkan bahwa waktu reaksi semakin melambat secara signifikan mulai dari fase menstruasi ke fase proliferasi dan ke fase sekretori. Hasil ini sesuai dengan penelitian sebelumnya yang menemukan hal yang sama yaitu waktu reaksi semakin melambat dari fase menstruasi ke fase sekretori. ${ }^{4}$ Terdapat perbedaan hasil yaitu pada penelitian sebelumnya, waktu reaksi visual pada fase menstruasi ke fase proliferasi melambat tetapi tidak signifikan secara statistik, ${ }^{4}$ sedangkan pada penelitian ini melambat secara signifikan. Hal ini dapat terjadi, kemungkinan karena pemakaian alat yang berbeda. Pada penelitian ini digunakan alat lakasidaya yang dibuat oleh Biro Konsultasi Kesehatan, Keselamatan, dan Produktivitas Kerja, sedangkan pada penelitian Kumar dkk menggunakan alat yang diproduksi oleh INCO instruments and chemicals PVT. ${ }^{4}$ Perbedaan hasil ini juga mungkin disebabkan oleh subjek penelitian pada penelitian ini adalah subjek penelitian yang berusia 20-21 tahun, sedangkan subjek pada penelitian sebelumnya berusia 18-25 tahun. ${ }^{4}$ Usia juga mempengaruhi waktu reaksi. ${ }^{2}$

Melambatnya waktu reaksi pada fase proliferasi dan sekretori kemungkinan disebabkan oleh retensi natrium dan air yang diakibatkan oleh perubahan hormon estrogen dan progesteron selama fase menstruasi. Retensi natrium dan air dapat menyebabkan konduksi saraf terganggu dan neurotransmiter yang tersedia di sinaps akan menurun. ${ }^{12}$ Kemungkinan lainnya melambatnya waktu reaksi pada fase proliferasi dan sekretori adalah hormon estrogen menurunkan jumlah reseptor serotonin di korteks frontalis dan korteks motorik, sehingga memodulasi transmisi dari neurotransmiter GABA. Neurotransmiter GABA menyebabkan masuknya ion klorida ke dalam sel, menyebabkan membran menjadi hiperpolarisasi, sehingga konduksi saraf melambat dan waktu reaksi melambat. ${ }^{13}$

Grafik kedua menunjukkan bahwa setelah 10 menit meminum kopi, didapatkan waktu reaksi yang lebih cepat dibandingkan sebelum minum kopi. Hal ini ditemukan pada semua fase menstruasi. Hasil ini menunjukkan efek positif dari minum kopi terhadap waktu reaksi pada seorang perempuan, karena pada saat fase proliferasi dan terutama fase sekretori waktu reaksi melambat (Gambar 1), dan minum kopi dapat mengurangi efek perlambatan waktu reaksi karena perubahan hormonal dari fase menstruasi. Melambatnya waktu reaksi dapat menggangu produktivitas kerja seorang perempuan, terutama yang mengandalkan 
respons yang cepat seperti pilot, pekerja pabrik, atlet, dan lain sebagainya. ${ }^{14-16}$ Dengan mengonsumsi kopi 10 menit sebelum mulai bekerja, terutama ketika perempuan sedang dalam fase proliferasi dan sekretori, diharapkan dapat membantu meningkatkan kinerja mereka.

Hasil penelitian ini sesuai dengan penelitian Anitei dkk yang menemukan peningkatan kecepatan waktu reaksi, reaktivitas motorik, dan atensi jangka pendek pada lakilaki dan perempuan yang mengonsumsi kafein dan minuman berenergi. ${ }^{16} \mathrm{Hal}$ yang sama juga ditemukan oleh Wardana $\mathrm{dkk}$, yaitu terjadi peningkatan kecepatan waktu reaksi 30 menit setelah minum kopi, tetapi tidak terjadi perubahan waktu reaksi satu jam setelah minum kopi, dengan subjek penelitian yang digunakan adalah laki-laki. ${ }^{5}$

Peningkatan kecepatan waktu reaksi setelah minum kopi, disebabkan oleh zat kafein yang terdapat pada kopi. Kafein dapat meningkatkan waktu reaksi karena bekerja sebagai psiko-stimulan melalui mekanisme penghambatan reseptor adenosin $\mathrm{A}_{1}$ dan $\mathrm{A}_{2}$, yang menyebabkan peningkatan penglepasan neurotransmiter dopamin, noradrenalin, dan glutamat, sehingga meningkatkan kinerja otak. ${ }^{8}$ Peningkatan waktu reaksi juga mungkin disebabkan karena kafein dapat meningkatkan tonus simpatis. ${ }^{17}$ Peningkatan kinerja otot rangka juga dipengaruhi oleh kafein, ${ }^{18}$ yang juga menjadi faktor peningkatan waktu reaksi, karena pemeriksaan waktu reaksi memerlukan koordinasi penglihatan, pemprosesan stimulus di otak, dan kerja dari otot rangka sebagai efektor.

\section{Simpulan}

Waktu reaksi pada perempuan sangat dipengaruhi oleh fase-fase pada siklus menstruasi. Perubahan waktu reaksi berturutturut dari yang tercepat ke yang terlambat adalah sebagai berikut: fase menstruasi, fase proliferasi, dan fase sekretori. Konsumsi kopi dapat meningkatkan kecepatan waktu reaksi 10 menit setelah meminumnya dan peningkatan kecepatan waktu reaksinya terjadi pada semua fase siklus menstruasi yaitu fase menstruasi, fase proliferasi dan fase sekretori.

\section{Daftar Pustaka}

1. Khan ADY, Ashwini A, Malipatil B. Effect of body mass index and gender on visual and auditory reaction times in young adults. J of US-China Medical Sci. 2015;12:64-9.

2. Shelton J, Kumar GP. Comparison between auditory and visual simple reaction times. Neuroscience \& Medicine. 2010;1:30-2.

3. Malhotra V, Goel N, Ushadhar, Tripathi Y, Garg R. Exercise and reaction times. J of Evolution of Med and Dent Sci. 2015;4:4277-81.

4. Kumar S, Mufti M, Kisan R. Variation of reaction time in different phases of menstrual cycle. J Clin Diagn Res. 2013;7(8):1604-5.

5. Wardana GA, Irwandi I, Soetjipto $H$. Effect of coffe drinks to the reaction time of 18-22 years old male university students. Folia medica Indonesiana. 2014;50:48-51.

6. Balakrishnan G, Uppinakudru G, Singh $\mathrm{GG}$, Bangera S, Raghavendra AD, Thangavel D. A comparative study on visual choice reaction time for different colors in females. Neurology Research International. 2014;301473:1-5

7. Mussato SI, Machado EMS, Martins S, Teixeira JA. Production, compotition, and application of coffee and its industrial residues. Food Bioprocess Techno. 2011;4:661-72.

8. Cappelletti S, Piacentino D, Sani G, Aromatario M. Caffeine: cognitive, and physical performance enhancer or psychoactive drug? Current Neuropharmacology. 2015;13:71-88.

9. Allen AM, Mc Rae-Clark AL, Carlson S, Saladin ME, Gray KM, Wetherington CL, et al. Determining menstrual phase in human biobehavioral research: a review with recommendations. Exp Clin Psychopharmacol. 2016;24(1):1-11.

10. Herwood L. Introduction to human physiology. $\quad 8^{\text {th }}$ ed. China: Brooks/Cole;2013.

11. Yogisutanti G, Kusnanto H, Setyawati L, Otsuka Y. Kebiasaan makan pagi, lama tidur, dan kelelahan kerja pada dosen. Jurnal Kesehatan Masyarakat. 2013;1:537.

12. Pawar BL, Kulkarni MA, Syeda A, Somwanshi ND, Chaudhari SP. Effect of premenstrual stress on cardiovascular system and central nervous system. J Obstet Gynecol India. 2006;56(2):156-8 
13. Veena CN, Vastrad BC, Nandan TM. Study of auditory and visual reaction time across various phases of menstrual cycle. National Journal of Physiology, Pharmacy, and Pharmacology. 2016;7:339-42.

14. Jain A, Bansal R, Kumar A, Singh KD. A comparative study of visual and auditory reaction times on basis of gender and physical activity level of medical first year students. Int J Appl Basic Med Res. 2015;5(2)124-7.

15. Hemamalini RV, Krishnamurthy N, Saravanan A. Influence of rotating shift work on visual reaction time and visual evoked potential. Journal of Clinical and Diagnostic Research. 2014;8(10):4-7.1
16. Anitei M, Schuhfried G, Chraif M. The influence of energy drinks and caffeine on time reaction and cognitive processes in young romanian students. Elsevier. 2011;30:662-70.

17. Corti R, Binggeli C, Sudano I, Spieker L, Hanseler E, Ruschitzka F, Chaplin WF, et al. Coffee acutely increases sympathetic nerve activity and blood pressure indepently of caffeine content. Circulation. 2002;106:2935-40.

18. Tallis J, Duncan MJ, James RS. What can isolated skeletal muscle experiments tell us about the effects of caffeine on exercise per ormance? BJP. 2015;172:3703-13. 